\title{
QUANTIFICATION OF LEAF GREENNESS AND LEAF SPECTRAL PROFILE IN PLANT DIAGNOSIS USING AN OPTICAL SCANNER
}

\author{
Quantificação do nível de verde e padrão espectral foliar no \\ diagnóstico de plantas através de um scanner ótico
}

\author{
Ryoichi Doi ${ }^{1}$
}

\begin{abstract}
Observation of leaf spectral profile (color) enables suitable management measures to be taken for crop production. An optical scanner was used: 1) to obtain an equation to determine the greenness of plant leaves and 2) to examine the power to discriminate among plants grown under different nutritional conditions. Sweet basil seedlings grown on vermiculite were supplemented with one-fifth-strength Hoagland solutions containing $0,0.2,1,5,20$, and $50 \mathrm{mM} \mathrm{NH}_{4}^{+}$. The $5 \mathrm{mM}$ treatment resulted in the greatest leaf and shoot weights, indicating a quadratic growth response pattern to the $\mathrm{NH}_{4}^{+}$gradient. An equation involving $b^{*}$, black and green to describe the greenness of leaves was provided by the spectral profiling of a color scale for rice leaves as the standard. The color scale values for the basil leaves subjected to 0.2 and $1 \mathrm{mM} \mathrm{NH}_{4}^{+}$treatments were 1.00 and 1.12 , respectively. The other treatments resulted in significantly greater values of 2.25 to 2.42 , again indicating a quadratic response pattern. Based on the spectral data set consisting of variables of red-green-blue and other color models and color scale values, in discriminant analysis, $81 \%$ of the plants were correctly classified into the six $\mathrm{NH}_{4}^{+}$treatment groups. Combining the spectral data set with the growth data set consisting of leaf and shoot weights, $92 \%$ of the plant samples were correctly classified whereas, using the growth data set, only $53 \%$ of plants were correctly classified. Therefore, the optical scanning of leaves and the use of spectral profiles helped plant diagnosis when biomass measurements were not effective.
\end{abstract}

Index terms: Color models, multidimensionality, multivariate spectral profiling, nonlinear response pattern, Ocimum basilicum.

\section{RESUMO}

A observação do perfil espectral da folha (cor) permite medidas de gestão adequadas a serem consideradas na produção. Um scanner óptico foi usado para: 1) obter uma equação para determinar o verde das folhas e 2) examinar o poder de discriminar entre as plantas cultivadas sob diferentes condições nutricionais. Mudas de manjericão cultivadas em vermiculita foram suplementadas com solucão de Hoagland contendo um quinto de força e suplementado com 0, 0,2, 1, 5, 20 e $50 \mathrm{mM} \mathrm{NH}_{4}^{+}$. O tratamento de 5 $\mathrm{mM}$ resultou em maior peso de folha e parte aérea, indicando um padrão de resposta quadrática para o gradiente de $\mathrm{NH}^{+}$. Uma equação envolvendo $b^{*}$, preto e verde para descrever o verde das folhas foi fornecido pelo perfil espectral de uma escala de cores para folha de arroz como padrão. Os valores de cor de escala para as folhas de manjericão submetidos aos tratamentos $\mathrm{NH}_{4}^{+}$ contendo 0,2 e $1 \mathrm{mM}$ foram 1,00 e 1,12, respectivamente. Os outros tratamentos resultaram em valores significativamente superiores, de 2,25 a 2,42 indicando novamente um padrão de resposta quadrática. Com base no conjunto dos dados espectrais constituído por variáveis de cores vermelho-verde-azul e outros modelos de cores e valores da escala de cores, na análise discriminante, $81 \%$ das plantas foram corretamente classificadas em a seis $\mathrm{NH}_{4}^{+}$grupos da planta. Combinando os dados espectrais com os dados de crescimento composto pelo peso das folhas e parte aérea, $92 \%$ das amostras de plantas foram corretamente classificadas, enquanto que usando somente o conjunto de dados de crescimento, apenas $53 \%$ das plantas foram corretamente classificadas. Neste contexto, a digitalização óptica das folhas e do uso de perfis espectrais auxiliou no diagnóstico da planta, quando as medidas da biomassa não foram efitivas.

Termos para indexação: Modelos de cores, a multidimensionalidade, perfil espectral multivariada, padrão de resposta não-linear, Ocimum basilicum.

(Received in april 25, 2012 and approved in june 4, 2012)

\section{INTRODUCTION}

For stable crop production, observations of crop responses to the given environmental conditions are important so that suitable management measures can be taken for the given environmental conditions. A variety of methods to observe crop responses to environmental conditions have been established (PLANT, 2001). To confirm if the environmental conditions are suitable for the crop, observations of above-ground morphological features (JALEEL et al., 2009) and spectral appearance (GAUSMAN et al. 1984) are often applied in addition to precise physical or chemical analyses of leaves and other above-ground biomass, such as determination of leaf nitrogen content (FRIDGEN; VARCO, 2004). Although

\footnotetext{
${ }^{1}$ The University of Tokyo - 1-1-1 - Yayoi - 113-8657 - Bunkyo-ku - Tokyo - Japan - roird2000@yahoo.com
} 
precise analyses of above ground biomass such as determination of leaf nitrogen compounds connect us to the fundamental mechanisms in the plant body, observations of the external appearance of the crop provide information regarding the results of various processes in the plant body with low cost, less time and labor, and greater user-friendliness.

One feasible method for the above ground observation of crops is the spectral profiling of the leaves (GAUSMAN et al. 1984). Leaf color is an indicator of plant condition. As a component of the red-green-blue color model, green is the color of chlorophyll, which generates energy (SHUVALOV, 2007). An abnormality in leaf color indicates a disorder of the plant body caused by aboveground stresses (SICHER, 1999) or poor soil conditions (OLSZEWSKA et al., 2008). It is thus evident that observation of leaf color enables suitable plant management measures (VAN NIEL; MCVICAR 2004). Recently, Zhang et al. (2010) utilized an optical scanner for the spectral profiling of rice leaves and successfully estimated the chlorophyll contents of the leaves based on the values of the red-green-blue and other color models. They also obtained multiple regression formulae to describe the contents of chlorophylls a and b. Their case study suggested that, using an optical scanner, a color scale for measuring leaf color greenness (FURUYA, 1987) may be applicable to plant diagnosis. The gradient of greenness shown by the color scale has a fairly close correlation with leaf chlorophyll content (BYJU; ANAND, 2009), which sensitively reflects environmental suitability for the crop, especially soil nitrogen availability (VARINDERPAL-SINGH et al., 2010). A simple statistical technique was expected to give a continuous measure of leaf greenness though the color scale has only seven colors represented by green plastic plates (DOI, 2010).

Given this, the first objective of this study was to examine the optical scanning method in the measurement of the greenness of basil leaves subjected to nitrogendeficiency and nitrogen-excess treatments. A continuous measure of greenness based on the spectral profiling of the color scale was applied to determine the greenness of basil leaves. The second objective was to examine the diagnostic use of the scanner-captured leaf spectral profiles by evaluating the discriminatory power to discriminate among the basil leaves. Sweet basil seedlings were grown on media supplemented with nitrogen-deficient to nitrogenexcess mineral solutions. As a prerequisite for the nutritional diagnosis, the discriminatory power of the profiling method relying on spectral variables was quantified.

\section{MATERIALS AND METHODS}

\section{Preparation of plant samples}

Seeds of a sweet basil cultivar (Ocimum basilicum), Sweet Green (Unwins Ltd., UK) were sown on vermiculite supplemented with water, and grown at 25 to $34^{\circ} \mathrm{C}$ and in a $12 \mathrm{~h}$ day (1420 lux $)-12 \mathrm{~h}$ night cycle for 19 days. The light source was a white light fluorescent lamp, Noabright (Noa Enterprises Co., Ltd., Japan). The vermiculite was pre-washed with deionized water. Two seedlings were then transplanted into a plastic cup with $15 \mathrm{~g}\left(105^{\circ} \mathrm{C}\right.$ oven-dried weight $)$ of vermiculite, and grown under the same temperature and light conditions. Five milliliters of one-fifth-strength Hoagland solution (pH 6.2) supplemented with 0. 0.2. 1, 5, 20, or $50 \mathrm{mM}$ $\mathrm{NH}_{4} \mathrm{Cl}$ were added five times to the plastic cup at intervals of 8 to 12 days. Within the interval period, water was occasionally added to the cup to maintain water availability for the plants. The plants were harvested 54 days after the transplantation. The shoot fresh weight was measured and the first leaf pair was separately weighed. The leaf pair was used for leaf spectral profiling using the optical scanner, Epson ES-2000, as described below. Four plastic cups were used for each $\mathrm{NH}_{4}^{+}$concentration, and eight replicate plants were obtained. The electrical conductivity and $\mathrm{pH}$ of the vermiculite medium at harvest time were determined as previously described (DOI; RANAMUKHAARACHCHI, 2009).

\section{Leaf color scale for the continuous measure of leaf greenness}

A color scale (Fujihira Industry Co., Ltd., Japan) for rice was used. The scale has seven greenish color levels that were spectral profiled using the Epson ES-2000 optical scanner. Each color level was scanned at 300 dots per inch in the color mode. The images of the color levels were saved as jpg files, and spectral profiles of the color levels were obtained by reading the intensity values of luminosity, red, green, blue, cyan, magenta, yellow, black, and $L^{*}$ and values of $a^{*}$ and $b^{*}$ with Adobe Photoshop ${ }^{\mathrm{TM}} 7.0$ computer software (DOI; RANAMUKHAARACHCHI, 2010). The red-greenblue color model is an additive color model that uses transmitted light to display colors based on the various proportions and intensities of three primary colors (red, green, and blue) to obtain a certain color (KAKUMANU et al., 2007). The three primary colors combine to transmit all light and thus produce white. The cyan-magenta-yellow-black model is based on the light-absorbing quality of the color (TOULIOS et al., 1998). As white light strikes translucent inks, some visible wavelengths are absorbed, and others are reflected. Three primary colors (cyan, magenta, and 
yellow) and black are used to create other colors. The International Commission on Illumination $L^{*} a^{*} b^{*}$ color model is designed to approximate human vision (KAKUMANU et al., 2007). The three coordinates of CIE $L^{*} a * b^{*}$ represent the lightness of the color $\left(L^{*}\right)$, its position between $\mathrm{red} / \mathrm{magenta}$ and green $\left(a^{*}\right)$, and its position between yellow and blue $\left(b^{*}\right)$. The relationships between changes in scale value between 1 (the lightest) and 7 (the darkest) and those in the spectral variables described above were statistically analyzed to obtain a formula to determine color scale values for the basil leaves.

\section{Leaf spectral profiling}

The upper (adaxial) surface of leaf pairs was scanned and spectral profiled as described above. Values of the spectral variables were read for 1113 or more pixels per leaf pair.

\section{Data analysis}

The statistical software SPSS10.0.1 (SPSS Inc.) was used to perform all of the following statistical analyses. Analysis of variance was performed to examine the significant effect of $\mathrm{NH}_{4}^{+}$concentration on each single variable. As the post hoc test, Fisher's least significant difference $t$-test was performed to evaluate the significance of the observed differences between means. Multiple regression analysis was performed to obtain a formula to determine color scale values for sample leaves applying the default criteria ( $p=0.05$ for inclusion and 0.10 for removal). To determine the discriminatory power of the profiling methods based on growth (leaf and shoot weights) and the spectral data sets to discriminate among the plants subjected to different $\mathrm{NH}_{4}^{+}$treatments, discriminant analysis was performed. Principal component analysis was performed to extract the principal components from a combined data set consisting of all growth and spectral variables to determine the dimensions that are independent.

\section{RESULTS AND DISCUSSION}

\section{Plant growth under the $\mathrm{NH}_{4}^{+}$treatments}

Table 1 presents the effects of $\mathrm{NH}_{4}^{+}$in one-fifthstrength Hoagland solution on plant growth and the final values of the electrical conductivity and $\mathrm{pH}$ of the vermiculite media. According to the changes in fresh weights of the first leaf pair and shoot, $5 \mathrm{mMNH}_{4}^{+}$was the optimal concentration. The treatments with 20 and $50 \mathrm{mMNH}_{4}^{+}$resulted in decreases in the weights of the first leaf pair and shoot, indicating that the $\mathrm{NH}_{4}^{+}$concentrations were excessive and thus suboptimal. The treatments with $1 \mathrm{mM}$ and lower $\mathrm{NH}_{4}^{+}$concentrations also resulted in small leaves and shoots, indicating nitrogen deficiency. These results indicate that both excessive and deficient $\mathrm{NH}_{4}^{+}$treatments negatively affect basil growth. Hence, against the $\mathrm{NH}_{4}^{+}$gradient, quadratic patterns of changes in the plant growth variables were recognized. In the diagnosis, the apparent proximity between the plants suffering from nitrogen deficiency and nitrogen excess was expected to hinder the discrimination between them when the leaf and shoot weights were used.

Table 1 - Effects of $\mathrm{NH}_{4}^{+}$concentration in one-fifth-strength Hoagland solution on leaf weight, shoot weight, and final conditions of vermiculite medium.

\begin{tabular}{|c|c|c|c|c|c|c|c|c|}
\hline \multirow{3}{*}{$\begin{array}{l}\text { Treatment } \\
\left(\mathrm{mM} \mathrm{NH}_{4}^{+}\right)\end{array}$} & \multirow{2}{*}{\multicolumn{2}{|c|}{$\begin{array}{c}\text { Leaf fresh } \\
\text { weight }^{*}(\mathrm{mg})\end{array}$}} & \multirow{2}{*}{\multicolumn{2}{|c|}{$\begin{array}{l}\text { Shoot fresh } \\
\text { weight (mg) }\end{array}$}} & \multicolumn{4}{|c|}{ Final conditions of medium } \\
\hline & & & & & \multicolumn{2}{|c|}{$\mathrm{EC}^{* *}(\mu \mathrm{S} / \mathrm{cm})$} & \multicolumn{2}{|c|}{$\mathrm{pH}$} \\
\hline & Mean & $\mathrm{SD}^{\dagger}$ & Mean & $\mathrm{SD}$ & Mean & SD & Mean & SD \\
\hline 0 & $34^{\mathrm{d}}$ & 18 & $85^{\mathrm{d}}$ & 28 & $120^{\mathrm{c}}$ & 17 & $6.68^{\mathrm{a}}$ & 0.13 \\
\hline 0.2 & $52^{\mathrm{cd}}$ & 15 & $118^{\mathrm{cd}}$ & 22 & $124^{\mathrm{c}}$ & 10 & $6.70^{\mathrm{a}}$ & 0.04 \\
\hline 1 & $85^{\mathrm{bc}}$ & 14 & $185^{\mathrm{bc}}$ & 34 & $121^{\mathrm{c}}$ & 16 & $6.66^{\mathrm{a}}$ & 0.03 \\
\hline 5 & $150^{\mathrm{a}}$ & 28 & $359^{\mathrm{a}}$ & 129 & $198^{\mathrm{c}}$ & 24 & $6.26^{\mathrm{b}}$ & 0.13 \\
\hline 20 & $110^{\mathrm{b}}$ & 50 & $241^{\mathrm{b}}$ & 101 & $552^{\mathrm{b}}$ & 110 & $5.72^{\mathrm{c}}$ & 0.26 \\
\hline 50 & $109^{\mathrm{b}}$ & 55 & $234^{\mathrm{b}}$ & 151 & $1140^{\mathrm{a}}$ & 525 & $5.89^{c}$ & 0.12 \\
\hline ANOVA $^{\dagger \dagger}$ & $<0.001$ & & $<0.001$ & & $<0.001$ & & $<0.001$ & \\
\hline
\end{tabular}

\footnotetext{
* Weight of first leaf pair compound.

** Electrical conductivity.

$\uparrow$ Standard deviation.

${ }^{\dagger}$ Results of analysis of variance expressed as $p$ values, hypothesizing.

$\mathrm{NH}_{4}{ }^{+}$concentration as the significant source of variation.
} 
Decreases in leaf biomass due to excessive nitrogen supply have been observed for three-year-old grape plants (KELLE; KOBLET, 1995), citrus seedlings (LEA-COX; SYVERTSEN, 1996), barley seedlings (BRITTO; KRONZUCKER, 2002), and tobacco seedlings (PAL; OJHA, 1966). Table 1 shows that excessive $\mathrm{NH}_{4}^{+}$supply caused the increase in the electrical conductivity of the media in the 20 and $50 \mathrm{mM} \mathrm{NH}_{4}^{+}$treatments, suggesting that the vermiculite was saturated by $\mathrm{NH}_{4}^{+}$in these treatments (MORTLAND et al., 1963). The growth inhibition under the high $\mathrm{NH}_{4}^{+}$treatments was not due to an increase in $\mathrm{pH}$, as described in one case study in which ammonium nitrate was applied (PAL; OJHA, 1966). Rather, the mechanism in which the rhizosphere is acidified when more cations are consumed by roots than anions (ROMHELD et al., 1984) and $\mathrm{H}^{+}$is released to balance the electrical charge in the plant body (BRITTO; KRONZUCKER, 2002) was likely to have occurred in the current experiment.

\section{Greenness and spectral profiles of the leaves}

Table 2 shows linear relationships between color scale value and the spectral variables. Most spectral variables had significant linear relationships with color scale value. As color scale value increases, the intensity values of luminosity, red, cyan, magenta, black, and $L^{*}$ dropped, indicating that the larger the scale value the darker the color. The smaller values of $b^{*}$ for the large color scale values indicate more greenish color than for the smaller scale values, which are more yellowish.

Table 2 - Linear relationships between color scale value and spectral variables.

\begin{tabular}{lrrrr}
\hline \multicolumn{1}{c}{$\begin{array}{l}\text { Spectral } \\
\text { variable }\end{array}$} & \multicolumn{2}{c}{ Fitness } & & \\
\cline { 2 - 4 } Intercept $^{\dagger}$ & \multicolumn{2}{c}{$p$ value } & Slope $^{\dagger}$ \\
\hline Luminosity & 0.951 & $<0.001$ & 142 & -7.29 \\
Red & 0.947 & $<0.001$ & 141 & -8.42 \\
Green & 0.963 & $<0.001$ & 156 & -8.20 \\
Blue & 0.020 & 0.475 & 77 & 0.23 \\
\hline Cyan & 0.916 & $<0.001$ & 131 & -6.29 \\
Magenta & 0.964 & $<0.001$ & 191 & -6.94 \\
Yellow & 0.900 & $<0.001$ & 28 & 6.88 \\
Black & 0.963 & $<0.001$ & 248 & -9.28 \\
\hline$L^{*}$ & 0.966 & $<0.001$ & 158 & -7.95 \\
$a^{*}$ & 0.643 & $<0.001$ & 113 & 0.71 \\
$b^{*}$ & 0.994 & $<0.001$ & 168 & -4.29 \\
\hline
\end{tabular}

${ }^{\dagger}$ Color scale value.

$=$ intercept + slope $\times$ value of the spectral variable.
Linear multiple regression analysis of the data provided the following equation to describe the greenness of leaves as color scale values on a continuous measure (Figure 1).

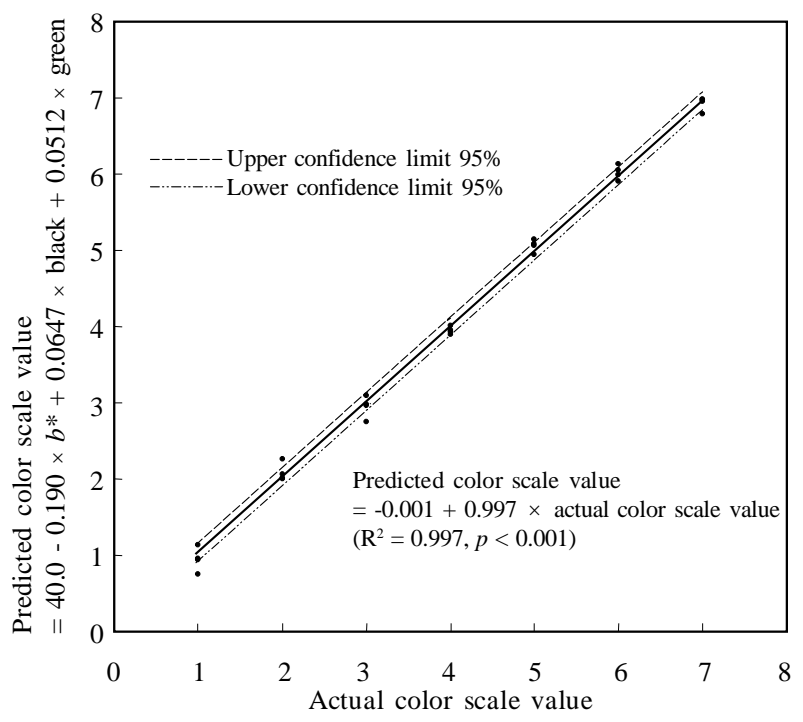

Figure 1 - Linear relationship between actual and predicted values of color scale for determination of greenness on the continuous measure described by the spectral variables.

Color scale value $=40.0-0.190 \times b^{*}+0.0647 \times$ back + $0.0512 \times$ green

The predicted color scale values felt in a narrow range of confidence limits (95\%) along the regression line with a great $\mathrm{R}^{2}$ value of 0.997 . As in a previous case study (DOI, 2010), the formula was shown to be a reliable continuous measure for determination of color scale vales for leaves when their values of $b^{*}$ and the intensity values of black and green are known.

By optical scanning of the leaves, the leaf spectral profiles were provided (Table 3). Again, non-linear quadratic relationships between the $\mathrm{NH}_{4}^{+}$gradient and changes in the spectral variables were seen. For example, the leaves that experienced the $1 \mathrm{mM} \mathrm{NH}_{4}^{+}$treatment had the largest values of the intensity of luminosity, red, and green, indicating that the leaves were light colored. The dark leaf spectral profile for the $0 \mathrm{mM} \mathrm{NH}_{4}^{+}$treatment was thought to be a result of the concentrating effect (BARNES et al., 1989) attributed to the poor leaf expansion while a certain amount of chlorophylls had been synthesized.

Ciênc. agrotec., Lavras, v. 36, n. 3, p. 309-317, maio/jun., 2012 


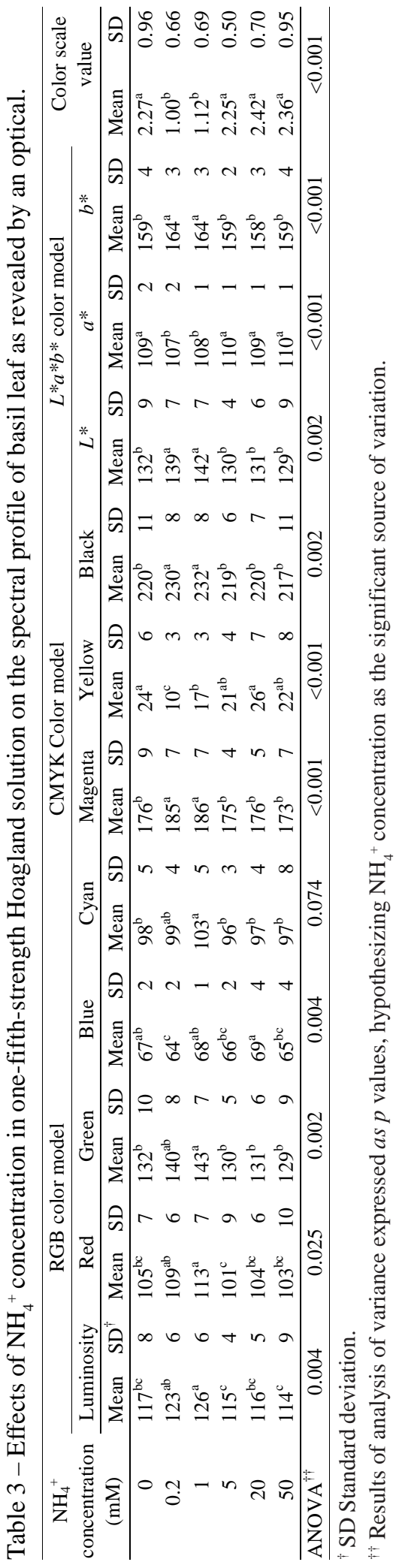

An apparently similar effect was observed under the 20 and $50 \mathrm{mM} \mathrm{NH}_{4}^{+}$treatments. The color scale values of around 2.4 were comparable to that for the $5 \mathrm{mM} \mathrm{NH}_{4}^{+}$ treatment (2.25) whereas the leaf weights were significantly smaller than that of the $5 \mathrm{mM} \mathrm{NH}_{4}^{+}$treatment. This indicates a decrease in chlorophyll synthesis in the basil leaves under the excessive $\mathrm{NH}_{4}^{+}$treatments (SANDOVAL-VILLA et al., 1999), but the decrease was masked by the significant decrease in the leaf biomass caused by the toxicity of $\mathrm{NH}_{4}{ }^{+}$per se as in the case of hydroponically grown tomato at $11 \mathrm{mM} \mathrm{NH}_{4}^{+}$(SIDDIQI et al., 2002).

The color scale values fell within a relatively low range (1.00-2.42) when compared with leaves of rice cultivars such as Sasanishiki for which the range of color scale value is between 3 and 5 or greater (TAKEBE; YONEYAMA, 1989). The light color of the basil leaves may be due to the weak light intensity for basil for which the optimal light intensity is much greater (BEAMAN et al., 2009) and/or to the limited wavelengths of the light emitted from the lamp (KOPSELL et al., 2005). The color scale was developed for scoring the greenness of rice leaves (FURUYA, 1987). However, because the color scale values based on the optical scanning showed a deficiency and excess of nitrogen, the color scale value could be an aid for the management of vegetables by supplementing the continuous measure of leaf greenness described as equation. In the current study, however, because the spectral profiles of the leaves as a result of the deficient and the excess $\mathrm{NH}_{4}{ }^{+}$supply were similar, the data set on these spectral variables was expected to be ineffective for the diagnostic use to discriminate among the basil plants subjected to deficient and excessive amounts of $\mathrm{NH}_{4}^{+}$supply.

\section{Discrimination among plants grown on media with different $\mathrm{NH}_{4}^{+}$concentrations}

The expected difficulty in the discrimination among the plants grown under the $\mathrm{NH}_{4}{ }^{+}$treatments due to the quadratic response patterns to the $\mathrm{NH}_{4}{ }^{+}$gradient was shown as the poor discriminatory power of the profiling method based on the growth variables (leaf pair and shoot weights) (Table 4). When using the growth data set only, approximately half of the plant samples were misclassified. Better discrimination among the plants was achieved by using the spectral data set consisting of the spectral variables in table 2 and color scale value, with the misclassification rate of $19 \%$, seemingly owing to the larger number of variables (DOI 
et al., 2010). However, some leaf pair samples that experienced no nitrogen supply were misclassified as having been subjected to excessive nitrogen supply. This unreliability of the single data set was improved when the data sets were combined, thus all of the growth and spectral variables were used together, resulting in a $91.5 \%$ correctness in the classification. A few cases of misclassification were seen among the 0 to 1 or 5 to 50 $\mathrm{mM} \mathrm{NH}{ }_{4}^{+}$treatments. Thus, an $\mathrm{NH}_{4}^{+}$concentration between 1 and $5 \mathrm{mM}$ was suggested to be the nitrogen deficiency threshold below which the growth is suppressed (TANENTZAP; BAZELY, 2009). The value between 1 and $5 \mathrm{mM}$ was somewhat lower compared with the experiment conducted by ZHANG et al. (2005) in which $8 \mathrm{mM}$ nitrogen as $\mathrm{NO}_{3}^{-}$was provided to spinach in a hydroponic system. In the current study, the root zone was not saturated with water, and this was thought to be the cause of the apparently low threshold nitrogen concentration.

The above results indicate that the combination of the data sets facilitated the discrimination, compensating for each other's weakness. This is thought to be due to the multiple groups of variables that had different patterns of change against the $\mathrm{NH}_{4}^{+}$gradient shown as multiple mean separation patterns in tables 2 and 3, e.g., between leaf weight and value of $b^{*}$. This hypothesis was supported by results of the principal component analysis of the combined data set (Table 5). Three significant principal components (eigenvector $>1$, Kaiser 1960) were obtained. Among the three principal components, the first principal component was largely contributed by most of the spectral variables such as green, while the second and third principal components were the growth variables. These results show that the data sets represent different aspects of the basil's responses to the $\mathrm{NH}_{4}^{+}$gradient (DE SENA et al., 2000), and were therefore advantageous to combine for the diagnosis (DOI et al., 2010). Although most of the variables showed quadratic patterns of change against the $\mathrm{NH}_{4}^{+}$gradient, there also existed different quadratic patterns between the groups of variables that showed plant responses to the $\mathrm{NH}_{4}^{+}$gradient.

Table 4 - Predicted group membership of basil leaves as a result of discriminant analyses of the growth, spectral, and combined data sets.

\begin{tabular}{|c|c|c|c|c|c|c|c|c|c|c|c|c|c|c|c|c|c|c|}
\hline \multirow{2}{*}{$\begin{array}{c}\mathrm{NH}_{4}^{+} \\
\text {Concentration }(\mathrm{mM})\end{array}$} & \multicolumn{6}{|c|}{ Growth data set only * } & \multicolumn{6}{|c|}{ Spectral data set only $* *$} & \multicolumn{6}{|c|}{ Combined data set ${ }^{\dagger}$} \\
\hline & 0 & 0.2 & 1 & 5 & 20 & 50 & 0 & 0.2 & 1 & 5 & 20 & 50 & 0 & 0.2 & 1 & 5 & 20 & 50 \\
\hline 0 & 6 & 2 & 0 & 0 & 0 & 0 & 5 & 0 & 1 & 0 & 2 & 0 & 6 & 0 & 2 & 0 & 0 & 0 \\
\hline 0.2 & 1 & 7 & 0 & 0 & 0 & 0 & 0 & 8 & 0 & 0 & 0 & 0 & 0 & 8 & 0 & 0 & 0 & 0 \\
\hline 1 & 1 & 0 & 7 & 0 & 0 & 0 & 1 & 0 & 7 & 0 & 0 & 0 & 1 & 0 & 7 & 0 & 0 & 0 \\
\hline 5 & 0 & 0 & 0 & 3 & 4 & 1 & 0 & 0 & 0 & 6 & 1 & 1 & 0 & 0 & 0 & 8 & 0 & 0 \\
\hline 20 & 0 & 2 & 0 & 5 & 1 & 0 & 0 & 0 & 0 & 1 & 7 & 0 & 0 & 0 & 0 & 1 & 7 & 0 \\
\hline 50 & 2 & 0 & 0 & 4 & 0 & 1 & 0 & 1 & 0 & 1 & 0 & 5 & 0 & 0 & 0 & 0 & 0 & 7 \\
\hline
\end{tabular}

* Weights of the first leaf pair and shoot.

** Intensity values of luminosity, red, green blue, cyan, magenta, yellow, black, and $L^{*}$, values of $a^{*}$ and $b^{*}$, and color scale value.

${ }^{\dagger}$ Growth and spectral data sets combined. 
Table 5 -Eigenvectors for growth and spectral variables provided by principal component analysis of the combined data set ${ }^{\dagger}$.

\begin{tabular}{lcccc}
\hline Principal component & & 1 & 2 & 3 \\
Eigenvalue & & 9.75 & 2.16 & 1.6 \\
Percentage explained $(\%)$ & & 70 & 15 & 11 \\
\hline Growth variable & Leaf fresh weight & -0.33 & -0.57 & 0.73 \\
& Shoot fresh weight & -0.32 & -0.53 & 0.76 \\
\hline Spectral variable & Luminosity & 0.98 & 0.11 & 0.13 \\
& Red & 0.93 & 0.23 & 0.10 \\
& Green & 0.99 & 0.03 & 0.10 \\
& Blue & 0.17 & 0.82 & 0.50 \\
& Cyan & 0.86 & 0.36 & 0.22 \\
& Magenta & 0.99 & -0.04 & 0.06 \\
& Yellow & -0.66 & 0.67 & 0.32 \\
& Black & 0.99 & -0.01 & 0.10 \\
& $L^{*}$ & 0.99 & 0.07 & 0.12 \\
& $a^{*}$ & -0.84 & 0.36 & 0.11 \\
& $b^{*}$ & 0.96 & -0.24 & -0.06 \\
\hline
\end{tabular}

The growth and the spectral data sets combined (see Table 4).

\section{CONCLUSIONS}

This case study demonstrated the feasibility of the current plant diagnostic method. Widely available optical scanners can provide digital images of leaves. The greenness of the leaves can be easily and accurately calculated using the values of $b^{*}$, and the intensity values of black and green for the leaves. Furthermore, the spectral data set assisted in the plant nutritional diagnosis that was based on the less reliable growth data set consisting of leaf and shoot weights. Because the leaf spectral profile often shows the physiological condition of the plant, this simple scanning and profiling method is worth considering, developing, and improving for applications in the management of crop production sites.

\section{ACKNOWLEDGEMENTS}

Ryoichi DOI is grateful to the Japanese Society for Promotion of Science for the Grant-in-Aid 22880011.

\section{REFERENCES}

BARNES, A.M.; WALSER, R.H.; DAVIS, T.D. Anatomy of Zea mays and Glycine max seedlings treated with triazole plant-growth regulators. Biologia Plantarum, Praha, v.31, n.5, p.370-375, 1989.

BEAMAN, A.R.; GLADON, R.J.; SCHRADER, J.A. Sweet basil requires an irradiance of $500 \mu \mathrm{mol} \mathrm{m}-2 . \mathrm{s}-1$ for greatest edible biomass production. HortScience, Alexandria, v.44, n.1, p.64-67, 2009.

BRITTO, D.; KRONZUCKER, H. NH4+ toxicity in higher plants: A critical review. Journal of Plant Physiology, Jene, v.159, n.6, p.567-584, 2002.

BYJU, G.; ANAND, M.H. Leaf color chart and chlorophyll-meter-based leaf nitrogen estimation and their threshold values for real-time nitrogen management in cassava. Communications in Soil Science and Plant Analysis, Philadelphia, v.40, n.1718, p.2816-2832, 2009.

DE SENA, M. et al. Evaluation of the use of chemometric methods in soil analysis. Quimica Nova, São Paulo, v.23, n.4, p.547-556, 2000.

DOI, R. Physicochemical quantitative determination by multivariate profiling of color and statistic method.

Patent application number 2010-097396, Japan. 3 April 2010.

DOI, R.; RANAMUKHAARACHCHI, S.L.

Correlations between soil microbial and physicochemical variations in a rice paddy: Implications for assessing soil health. Journal of Biosciences, Bangalore, v.34, n.6, p.969-976, 2009. 
DOI, R.; RANAMUKHAARACHCHI, S.L.

Discriminating between canopies of natural forest and Acacia plantation plots in a Google Earth image to evaluate forest land rehabilitation by Acacia species. International Journal of Agriculture and Biology, Faisalabad, v.12, n.6, p.921-925, 2010.

DOI, R. et al. Semiquantitative color profiling of soils over a land degradation gradient in Sakaerat, Thailand. Environmental Monitoring and Assessment, Dordrecht, v.170, n.1-4, p.301-309, 2010.

FRIDGEN, J.L.; VARCO, J.J. Dependency of cotton leaf nitrogen, chlorophyll, and reflectance on nitrogen and potassium availability. Agronomy Journal, Madison, v.96, n.1, p.63-69, 2004.

FURUYA, S. Growth diagnosis of rice plants by means of leaf color. JARQ-Japan Agricultural Research Quarterly, Tsukuba, v.20, n.3, p.147-153, 1987.

GAUSMAN, H.W.; BURKE, J.J.; QUISENBERRY, J.E. Use of leaf optical-properties in plant stress research. ACS Symposium Series, Washington, v.257, p.215-233, 1984.

JALEEL, C.A. et al. Drought stress in plants: A review on morphological characteristics and pigments composition. International Journal of Agriculture and Biology, Faisalabad, v.11, n.1, p.100-105, 2009.

KAISER, H.F. The application of electronic computers to factor analysis. Educational and Psychological Measurement, Thousand Oaks, v.20, n.1, 141-151. 1960.

KAKUMANU, P.; MAKROGIANNIS, S.; BOURBAKIS, N. A survey of skin-color modeling and detection methods. Pattern Recognition, Kidlington, v.40, n.3, 1106-1122, 2007.

KELLER, M.; KOBLET, W. Dry-matter and leaf-area partitioning, bud fertility and second season growth of Vitis vinifera L - responses to nitrogen supply and limiting irradiance. Vitis, Siebeldingen, v.34, n.2, p.77-83, 1995.

KOPSELL, D.A.; KOPSELL, D.E.; CURRANCELENTANO, J. Carotenoid and chlorophyll pigments in sweet basil grown in the field and greenhouse. HortScience, Alexandria, v.40, n.5, p.1230-1233, 2005.
LEA-COX, J.D.; SYVERTSEN, J.P. How nitrogen supply affects growth and nitrogen uptake, use efficiency, and loss from citrus seedlings. Journal of the American Society for Horticultural Science, Alexandria, v.121, n.1, p.105-114, 1996.

MORTLAND, M.M. et al. Interaction between ammonia and expanding lattices of montmorillinite and vermiculite. Journal of Physical Chemistry, Washington, v.67, n.2, p.248-258, 1963.

OLSZEWSKA, M. et al. Effect of phosphorus deficiency on gas exchange parameters, leaf greenness (SPAD) and yield of perennial ryegrass (Lolium perenne L.) and orchard grass (Dactylis glomerata L.). Journal of Elementology, Olsztyn, v.13, n.1, p.91-99, 2008.

PAL, N.L.; OJHA, R.J. Tobacco seedlings - damage by excessive nitrogen lessened by added phosphorus. Science, Washington, v.151, n.3706, p.106, 1966.

PLANT, R.E. Site-specific management: The application of information technology to crop production. Computers and Electronics in Agriculture, Kidlington, v.30, n.1-3, p.9-29, 2001.

ROMHELD, V.; MULLER, C.; MARSCHNER, H. Localization and capacity of proton pumps in roots of intact sunflower plants. Plant Physiology, Lancaster, v.76, n.3, p.603-606, 1984.

SANDOVAL-VILLA, M.; WOOD, C.W.; GUERTAL, E.A. Ammonium concentration in solution affects chlorophyll meter readings in tomato leaves. Journal of Plant Nutrition, New York, v.22, n.11, p.1717-1729, 1999.

SHUVALOV, V.A. Electron and nuclear dynamics in many-electron atoms, molecules and chlorophyll-protein complexes: A review. Biochimica et Biophysica ActaBioenergetics, Amsterdam, v.1767, n.6, p.422-433, 2007.

SICHER, R.C. Photosystem-II activity is decreased by yellowing of barley primary leaves during growth in elevated carbon dioxide. International Journal of Plant Sciences, Chicago, v.160, n.5, p.849-854, 1999.

SIDDIQI, M.Y. et al. Effects of ammonium and inorganic carbon enrichment on growth and yield of a hydroponic tomato crop. Journal of Plant Nutrition and Soil Science, Malden, v.165, n.2, p.191-197, 2002. 
TAKEBE, M.; YONEYAMA, T. Measurement of leaf color scores and its implication to nitrogen nutrition of rice plants. JARQ-Japan Agricultural Research Quarterly, Tsukuba, v.23, n.2, p.86-93, 1989.

TANENTZAP, A.J.; BAZELY, D.R. Propagule pressure and resource availability determine plant community invasibility in a temperate forest understorey. Oikos, Malden, v.118, n.2, p.300-308, 2009.

TOULIOS, L.G; TOULIOS, M.G.; LIPIMENOU, E. Soil color relationships with reflectance spectra. Geocarto International, Hong Kong, v.13, n.2, p.35-42. 1998.

VAN NIEL, T.G.; MCVICAR, T.R. Current and potential uses of optical remote sensing in rice-based irrigation systems: A review. Australian Journal of Agricultural Research, Victoria, v.55, n.2, p.155-185, 2004.
VARINDERPAL-SINGH et al. Need based nitrogen management using the chlorophyll meter and leaf colour chart in rice and wheat in south asia: A review. Nutrient Cycling in Agroecosystems, Dordrecht, v.88, n.3, p.361-380, 2010.

ZHANG, Y. et al. Effects of nitrogen levels and nitrate/ ammonium ratios on oxalate concentrations of different forms in edible parts of spinach RID A-3552-2009. Journal of Plant Nutrition, New York, v.28, n.11, p.2011-2025, 2005.

ZHANG, D. et al. Estimating chlorophyll content of rice leaves on different layers based on scanning images. In: Proceedings of the 2nd International Conference on Information Science and Engineering, 4-6 December, 2010, Hangzou, China. 